\title{
PASAR MASYARAKAT DIGITAL DAN DEGRADASI NETIQUETTE
}

\author{
Fazrian Noor Ramadhon \\ Program Studi Magister Ilmu Komunikasi, Fakultas Ilmu Sosial dan Ilmu Politik Universitas Jenderal \\ Soedirman \\ noorfazrian7@gmail.com
}

\begin{abstract}
The development of communication in social media, increasingly creates opportunities as well as new challenges. The opportunity is the creation of new types of work that are more tempting and even favored by social media users. For example, Selebgram and YouTuber. Being a celebrity or YouTuber, is one of the effects of the development of social media. Someone can work also to make money, only with a lot of capital that virtual friends network has on social media. The more networked virtual friends, the more potential the coffers of money won. Even more deeply, users will increasingly have the potential to be known and known as being an artist. However, this new opportunity also creates new challenges in social media, one of which is ethical degradation in social media (netiquette). The impact, cyber bullying, hate speech, sexual harassment, became a common risk when deciding to use social media. This is a hard challenge for the Stone Head Audience Theory. This criticism theory says that society is not just accepting whatever is conveyed by social media, but an active role in digesting it to provide a response back to social media. This study uses a qualitative descriptive method with the aim of analyzing the opportunities and challenges of social media for netiquette.
\end{abstract}

Keywords - Digital Community Market, Netiquette, Theory of Stone Head Audiences

\begin{abstract}
ABSTRAK
Perkembangan komunikasi dalam bermedia sosial, semakin menciptakan peluang juga tantangan baru. Peluangnya yaitu terciptanya pekerjaan jenis baru yang lebih menggiurkan bahkan digemari oleh pengguna media sosial. Misalnya, Selebgram dan YouTuber. Menjadi seorang Selebgram ataupun YouTuber, merupakan salah satu dampak dari perkembangan media sosial. Seseorang bisa bekerja juga menghasilkan uang, hanya dengan modal banyak jejaring teman maya yang dimiliki di media sosial. Semakin banyak jejaring teman maya, semakin berpotensi pula pundipundi uang yang diraih. Bahkan jauh lebih dalamnya, pengguna akan semakin berpotensi untuk dikenal dan terkenal layaknya menjadi seorang artis. Akan tetapi, peluang baru tersebut justru menciptakan pula tantangan baru dalam bermedia sosial, salah satunya yaitu degradasi etika dalam bermedia sosial (netiquette). Dampaknya, cyber bullying, hate speech, sexual harrasment, menjadi satu resiko lumrah ketika memutuskan untuk menggunakan media sosial. Hal inilah yang menjadi tantangan keras bagi Teori Khalayak Kepala Batu. Teori kritik ini mengatakan bahwa masyarakat tidak hanya sekedar menerima apapun yang disampaikan media sosial, melainkan berperan aktif untuk mencerna hingga memberikan respon balik terhadap media sosial. Penelitian ini menggunakan metode deskriptif kualitatif dengan tujuan untuk menganalisa peluang dan tantangan media sosial bagi netiquette.
\end{abstract}

Kata Kunci: Pasar Masyarakat Digital, Netiquette, Teori Khalayak Kepala Batu 


\section{PENDAHULUAN}

Komunikasi yang pada awal mulanya hanya sebagai suatu proses pertukaran informasi diantara individu, seiring perkembangan zaman meluas menjadi suatu keniscayaan yang memiliki fungsi lain yang berkaitan pula dengan aspek-aspek lain. Di tengah perkembangan teknologi yang semakin pesat, misalnya. Komunikasi semakin berperan sebagai suatu keniscayaan yang mampu menghubungkan hingga membentuk satu hal. Perannya diakui dan berdampak nyata terhadap kehidupan. Perannya pula, diakui mampu membantu dalam berbagai aspek kehidupan, dari mulai kebutuhan sandang, pangan, papan, hingga menciptakan komunikasi gaya baru.

Teknologi yang dipercaya sebagai temuan mutakhir manusia, semakin mempermudah kehidupan manusia termasuk dalam hal berkomunikasi. Bahkan, keberadaannya berkaitan erat dengan komunikasi hingga mampu menciptakan berbagai temuan baru. Secara dinamis, komunikasi gaya baru pun bermunculan. Perlahan, komunikasi tradisional kian semakin tidak memiliki peran dan tergantikan oleh komunikasi gaya baru dengan bantuan teknologi. Hal ini tidak bisa terelakkan. Melihat perkembangan dunia pasca revolusi industri semakin pesan, serta berbagai temuan teknologi mutakhir diciptakan, teknologi saat ini menjadi suatu keniscayaan. Komunikasi berkembang, begitu pula dengan teknologinya. Keduanya memiliki nilai keniscayaan yang tidak bisa terbantahkan.
Satu diantara banyaknya keniscayaan tersebut adalah komunikasi digital/komunikasi maya. Sederhananya, komunikasi digitalmerupakankomunikasiyangdilakukan secara digital/maya dengan bantuan piranti teknologi. Yang menjadi nilai istimewa, melalui komunikasi digital, pengguna tidak hanya sekedar berkomunikasi. Akan tetapi, pengguna mampu membentuk suatu hal hingga menciptakan pekerjaan jenis baru. Hal inilah yang membuat komunikasi digital begitu diminati oleh semua kalangan. Hal ini pula, yang membuat masyarakat semakin terdigitalisasi hingga bergantung terhadap komunikasi digital. ${ }^{1}$

Mudah untuk ditemui bagaimana melihat perkembangan komunikasi digital. Salah satunya melalui media Instagram dan YouTube. Keduanya menjadi dampak nyata yang membuat banyak perubahan. Bahkan, keduanya pula yang memberikan peluang pekerjaan baru. Instagram dan YouTube menjadi pasar menggiurkan bagi para pengguna meski hanya di kalangan sesama teman maya. Pengguna hanya perlu mempublikasikan apapun secara ideal dan meyakinkan untuk terkenal dan dikenal. Setelahnya, pengguna pun harus mencari teman maya sebanyak-banyaknya agar apapun yang dipublikasikan, mampu tersebarluaskan ke seluruh teman maya. Semakin banyak teman maya, semakin berpeluang untuk meraih pundi-pundi uang. Istilahnya, orang tersebut dikenal dengan sebutan Selebgram dan YouTuber.

Selebgram, misalnya. Dengan memanfaatkan media Instagram, pengguna bisa 1 Liliweri, Alo. 2016. Konfigurasi Dasar Teori-Teori Komunikasi Antarbudaya. Bandung: Nusa Media. 
memperoleh uang hanya dari mempublikasikan foto saja asal memiliki banyak teman maya (follower). Tidak hanya itu, pengguna pun harus senantiasa memiliki image khas dan menarik, sehingga menarik perhatian orang lain untuk dijadikan sebagai media promosi. Istilah terkenalnya yaitu endorsement. Biasanya, pengguna yang sudah dikenal atau terkenal juga mempunyai banyak teman maya, mencantumkan nomor kontak yang bisa dihubungi pada profil keterangan Instagramnya. Hal itu agar siapapun yang ingin mempromosikan usaha melalui akun Instagramnya, mampu dengan mudah menghubunginya. Contoh berikutnya yaitu YouTuber. Menjadi seorang YouTuber merupakan salah satu jenis pekerjaan baru yang dihasilkan oleh media baru. Sama seperti Instagram, bedanya yang dipublikasikan melalui YouTube adalah video. Semakin banyak teman maya (subscriber), semakin berpotensi pula meraih banyak pundi-pundi uang. Lebih menggiurkannya lagi, ada monetisasi iklan yang akan diraih jika video yang diunggah sukses banyak ditonton.

Baik Instagram ataupun YouTube, keduanya memberikan peluang menjanjikan di tengah perkembangan ilmu pengetahun dan teknologi seperti saat ini. Bekerja hanya dengan mengandalkan media yang ada pada genggaman. Tidak perlu berangkat ke kantor juga mengenakan pakaian formal. Serta tidak perlu pula menunggu arahan dari atasan atas tugas yang diberikan. Melalui Instagram dan YouTube, pengguna hanya dituntut kreatif menciptakan satu hal untuk membentuk suatu citra/image bagi sesama teman maya. Tentu, menjadi seorang
Selebgram atau YouTuber, membutuhkan kerja keras yang tidak sedikit. Bahkan, jika dilihat lebih dalam, ada tanggung jawab besar yang berdampak serius jika diabaikan. Karena, seseorang yang bekerja secara maya, terlebih sudah dikenal dan terkenal, berpotensi ditiru serta dijadikan tauladan oleh sesama teman maya. Ada rasa ingin menyerupai agar mampu sejajar dengannya. Selain itu, seseorang yang bekerja secara maya pun, berpotensi untuk dikomentari dari berbagai sisi. Cyber bullying, hate speech, hingga sexual harassment, menjadi resiko yang sudah tidak asing lagi ketika membaca kolom-kolom komentar. Berkomentar tentu tidak salah, karena media sosial apapun diciptakan untuk senantiasa saling berkomentar/berkomunikasi. Yang justru amat sangat disayangkan dan masih dianggap sebelah mata yaitu ketika etika dan moral dalam berkomentarlah yang harus benar-benar diperhatikan.

Media sosial yang merupakan media tanpa ada batasan, membebaskan penggunanya untuk mempublikasikan hingga berkomentar apapun. Bahkan saking bebasnya, pengguna pun terbebaskan mengalir sebebas-bebasnya. Tidak peduli lawan komentar siapa, kawan komentar siapa, dan sikap lawan komentar bagaimana. Berkomentar sebebas-bebasnya lumrah dilakukan. Pemerintah pun sudah membuat regulasi dalam mengatur kebebasan berkomentar di media sosial agar tidak semakin memprihatinkan. Tapi tetap saja, komentar tanpa dasar etika dan moral masih mudah ditemukan. Antar pengguna saling bully, menyebar hate speech, dsb. Satu 
contoh diantara banyaknya kasus degradasi etika di media sosial yaitu kasus yang pernah dialami Gita Savitri Devi, seorang Selebgram juga YouTuber asal Indonesia yang tinggal di Jerman. Sehari-harinya ia tidak pernah absen di media sosial. Gitasav, panggilan akrabnya, pernah menerima cyber bullying hingga sexual harrasment di media sosial melalui kolom-kolom komentarnya. Isi komentarnya dari mulai dikatakan sebagai orang yang tidak memiliki fisik sempurna hingga dikatakan pantas untuk jadi wanita tunasusila. Membaca komentar seperti itu, Gitasav membagikankomentar-komentarnya tersebut, dikritisi, dan dibagikannya kembali di Insta story miliknya. Gitasav menilai, jika hal-hal demikian dibiarkan dan dianggap lumrah di media sosial, tentu akan semakin menyebabkan degradasi etika masyarakat. Masyarakat menjadi cenderung semakin tidak peduli bahkan abai terhadap perasaan juga kepekaan orang lain².

Maka dari itu, ini merupakan peluang juga tantangan dalam berkomunikasi di era perkembangan media dan teknologi seperti saat ini. Disaat media sosial menciptakan peluang lapangan pekerjaan jenis baru, disaat itu pula etika dan moral semakin mengalami degradasi. Fungsi-fungsi komunikasi semakin terjauhkan, juga patologi-patologi media sosial semakin bermunculan. Satu unsur penting dan dominan disini yaitu khalayak/ pengguna/masyarakat. Masyarakat menjadi unsur utama karena memiliki psikososiologis yang dianugerahi Tuhan memiliki kesadaran juga kepekaan terhadap sesama. Karena idealnya, perkembangan komunikasi

2 Instastory Gita Savitri Devi @Gitasav diikuti pula dengan perkembangen etika juga moral masyarakatnya.

\section{METODE}

Atas dasar latar belakang di atas, penulis tertarik untuk mengkajinya menggunakan metode deskriptif kualitatif dengan sumber data telaah pustaka dan salah satu akun Instagram Selebgram Gita Savitri Devi yang dianalisa menggunakan Teori Khalayak Kepala Batu. Akun Instagram Gita Savitri Devi dipilih karena secara virtual ia menjadi sosok berpengaruh yang bekerja sebagai Selebgram, YouTuber, juga Influencer. Karena pekerjaannya tersebut pula, ia dilecehkan oleh para netizen dengan berbagai komentar negatif.

\section{HASIL DAN PEMBAHASAN}

\section{Media Sosial dan Masyarakat Digital}

Sehari-hari, media sosial sudah menjadi hallumrahuntukdigunakan. Daribanguntidur hingga tidur kembali, media sosial menjadi hal yang tidak pernah lepas untuk diikuti. Kegiatannya dari mulai memperbarui status hari ini, mempublikasikan foto, membagikan sedang makan apa, dimana, dengan siapa, mendengarkan musik apa, dsb. Menurut Rulli Nasrullah, media sosial yaitu wadah ataupun media untuk mempresentasikan dirinya untuk berinteraksi, bekerjasama, berbagi, berkomunikasi, hingga membentuk ikatan sosial secara maya antar sesama pengguna lainnyas.

3 Nasrullah, Rulli. 2017. Media Sosial Perspektif Komuni-kasi, Budaya, dan Sosioteknologi. Bandung: Simbiosa Rekatama Media. 
Misalnya, berawal dari membagikan sedang makan apa dan dimana, sejumlah teman maya mengomentarinya beraneka ragam. Karena penasaran dan tergiur dengan apa yang dibagikan temannya tadi, orang yang berkomentar tadi pun dengan sengaja berangkat ke tempat makan yang dibagikan tadi. Disadari ataupun tidak, berawal dari membagikan sedang makan apa dan dimana tadi, pengguna telah berhasil berinteraksi dengan sesama pengguna lain hingga berujung pada ikatan sosial yang bertemu di tempat makan tadi. Semua serba mudah, cepat, dan terhubung. Bahkan, menurut Thomas L. Friedman, seorang Kolumnis New York Times dalam buku Media/Impact Pengantar Media Massa, menyampaikan bahwa pada saat ini dunia sudah terhubung menjadi satu yang menyebabkan pengguna tidak hanya melihat dari satu sisi. Hal tersebut dikarenakan adanya internet dan media yang telah mengubah struktur berkomunikasi di seluruh dunia.

Satu hal yang nampak jelas dari apa yang disampaikan Thomas L. Friedman diatas yaitu dengan berubahnya struktur berkomunikasidiseluruhdunia,makaberubah pula budaya masyarakatnya. Hal inilah yang disebut dengan budaya siber (cyberculture) yang menyatakan bahwa internet beserta media sosial didalamnya merupakan ruang pembentukan, pendistribusian, hingga penggunaan suatu budaya ${ }^{5}$. Tidak heran, masyarakat kini menjadi lebih serba digital dengan mengandalkan teknologi-teknologi.

\footnotetext{
4 Biagi, Shirley. 2010. Media/Impact Pengantar Media Massa. Jakarta: Salemba Humanika. Terjemahan.

5 Nasrullah, Rulli. 2017. Media Sosial Perspektif Komunikasi, Budaya, dan Sosioteknologi. Bandung: Simbiosa Rekatama Media.
}

Dan itu tidak hanya dalam berkomunikasi, melainkan termasuk kedalam kehidupan sehari-hari. Lebih tepatnya, masyarakat tersebut dikenal dengan masyarakat digital (digital society).

\section{Masyarakat Digital Sebagai Pasar}

Media sosial yang pada dasarnya bertitik tumpu pada sebuah jaringan pertemanan secara maya, ternyata mampu membentuk pasar tersendiri bagi sesama pengguna media sosial. Pasar tersebut adalah masyarakat digital yang akrab disebut dengan follower, friends, subscriber, dsb. Dalam kaitannya dengan media sosial, masyarakat digital tersebut menjadi sekelompok komersil yang bisa dimonetisasi. Tanpa ada batasan apapun, semua bisa memasarkan apapun asal memiliki banyak jaringan masyarakat digital. Maka jelas, segmentasi utama pada pasar media sosial yaitu masyarakat digital

Bahkan, menurut Dallas Smythe, mengungkapkan bahwa masyarakat digital bekerja sebagai pengiklan/penonton. Sadar atau tidak sadar, masyarakat digital rela menyempatkan waktu untuk hanya sekedar melihat foto-foto di Instagram ataupun menonton video-video di YouTube yang justru bagi pengguna yang membuatnya, akan menghasilkan pundi- pundi uang. Disaat nilai hiburan dikomersilkan, disaat itu pula masyarakat dieksploitasi secara ekonomi meski memang tidak sadar ${ }^{\circ}$.

\section{Teori Khalayak Kepala Batu}

Dalam beberapa literatur, teori ini

6 McQuail, Denis. 2011. Teori Komunikasi Massa. Jakarta: Salemba Humanika. Terjemahan. 
disebutkan sebagai teori kritik terhadap teori jarum hipodermik yang menyatakan bahwa khalayak tidak berdaya dan tidak mampu melawan media. Dalam artian, khalayak disini berperan pasif hanya sekedar menerima apa yang disampaikan media lalu mencernanya begitu saja. Akan tetapi, teori khalayak kepala batu membantah teori diatas yang menyatakan bahwa khalayak pada saat ini sangat berdaya juga mampu melawan media. Dalam artian, khalayak disini berperan aktif yang tidak hanya sekedar menerima apapun yang disampaikan media, melainkan mencernanya hingga menimbulkan respon balik terhadap media.

Maka, jika melihat realitas sekarang, khalayak ataupun masyarakat sudah mulai berperan aktif terhadap apapun yang disampaikan media, baik itu melalui tontonan, pemberitaan, dan media visual lainnya. Keaktifannya tersebut, dibuktikan dengan cara berkomentar, mengkritisi, hingga menciptakan suatu budaya baru. Melalui interaksi tersebutlah, media dan khalayak kini saling memiliki timbal balik yang mempengaruhi juga dipengaruhi ${ }^{7}$.

Akan tetapi, jika diperhatikan lebih dalam, berawal dari keaktifannya tersebut dalam menanggapi suatu hal di media sosial, masyarakat justru sangat aktif hingga terbebaskan melakukan apapun tanpa dasar etika. Alhasil, etika ketika menggunakan media sosial pun semakin terabaikan bahkan tidak diperhatikan sama sekali. Masyarakat bebas aktif berkomentar apapun, mengkritisi apapun, tanpa melihat dengan siapa lawan

7 Baran, Stanley J. 2012. Pengantar Komunikasi Massa Melek Media dan Budaya. Jakarta: Erlangga. interaksi berkomentar, bagaimana dampak yang terjadi jika berkomentar demikian, $\mathrm{dsb}^{8}$.

\section{Netiquette Masyarakat Digital}

Menurut Thurlow, yang disadur oleh Rulli Nasrullah, mengungkapkan bahwa netiquette berasal dari kata net yang berarti jaringan (network/internet) dan etiquette yang berarti etika atau tata nilai. Sederhananya, netiquette merupakan etika dalam menggunakan internet. ${ }^{9}$ Idealnya, jika melihat pandangan Thurlow tersebut, menggunakan internet termasuk media sosial didalamnya membutuhkan suatu etika yang sejatinya dipahami dan diterapkan bagi seluruh pengguna.

Sedikitnya, terdapat empat alasan utama mengapa harus beretika di media sosial, diantaranya:

1. Perbedaan latar belakang pengguna yang berbeda-beda, sejatinya menjadi batasan superego terlebih jika dikaitkan dengan norma-norma yang berlaku

2. Komunikasi yang terjadi di media sosial pada umumnya yaitu komunikasi non verbal atau menggunakan teks dan kode

3. Pandangan media sosial merupakan media yang sangat berbeda dengan dunia nyata

4. Media sosial tidak hanya sekedar memfasilitasi pengguna, akan tetapi sebagai institusi bisnis. ${ }^{10}$

8 Listiani, Endri dan Askurifa'l Baksin. 2013. Media dan Komunikasi Lingkungan. Bandung: Unisba.

9 Nasrullah, Rulli. 2017. Media Sosial Perspektif Komunikasi, Budaya, dan Sosioteknologi. Bandung: Simbiosa Rekatama Media.

10 Nasrullah, Rulli. 2017. Media Sosial Perspektif Komunikasi, Budaya, dan Sosioteknologi. Bandung: 
Maka dari itu, netiquette jelas menjadi landasan sikap utama yang penting untuk dipahami dan diterapkan disaat menggunakan media sosial. Mempublikasikan tidak hanya sekedar publikasi, pun berkomentar tidak hanya sekedar komentar tanpa didasari etika juga superego.

Maka dari itu, komunikasi dan masyarakat menjadi satu kesatuan yang tidak bisa terpisahkan. Keduanya akan saling berkaitan dan mempengaruhi satu sama lain. Terlebih di era media sosial, komunikasi dengan menggunakan media sosial menjadi salah satu hal yang lumrah digunakan. Antar satu masyarakat dengan masyarakat yang lain, meskipun terpaut jarak yang amat sangat jauh, kini bisa terasa dekat dengan adanya media sosial. Dan ini merupakan satu dari banyaknya kecanggihan teknologi dalam menembus batasan. Jarak, waktu, bahkan tempat sekalipun, menjadi tidak masalah dalam berkomunikasi dengan menggunakan media sosial.

Selain itu, dengan beberapa inovasi perkembangan fitur-fiturnya, media sosial saat ini bahkan tidak hanya sekedar dijadikan sebagai media untuk berkomunikasi. Melainkan, bisa digunakan sebagai sarana berjualan hingga membuka peluang pekerjaan jenis baru. Dari fungsinya yang tidak hanya sekedar berkomunikasi itu pun, media sosial saat ini menjadi salah satu media kontruksi budaya baru di kalangan masyarakat. Dari mulai mencari WiFi di setiap tempat hangout hanya untuk sign-in di media sosial, mengambil gambar makanan yang di pesan sebelum dimakan lalu mempublikasikannya Simbiosa Rekatama Media. di media sosial, mereview berbagai jenis produk lalu merekomendasikannya kepada sesama teman maya dan dipublikasikan di media sosial, hingga foto outfit of the day from head to toe yang kemudian dipublikasikan di media sosial.

Beberapa contoh budaya baru yang terbentuk melalui media sosial diatas, disadari atau tidak menjadi salah satu pasar masyarakat digital tertentu bagi para pebisnis. Atau bagi yang memiliki banyak teman maya di media sosialnya, pengguna bisa menjadi seorang Selebgram ataupun YouTuber, yang menciptakan peluang pekerjaan jenis baru melalui brand endorsement dan monetisasi iklan dari banyaknya penonton.

Inilah yang menjadi nilai peluang ditengah perkembangan komunikasi juga media sosial didalamnya, diikuti dengan perkembangan masyarakat yang memanfaatkan peluang melalui perkembangan media. Terlebih pada aspek masyarakat yang pada dasarnya memiliki struktur id, ego, dan superego, mampu menciptakan budaya hingga perilaku baru. Belum usai sampai sini, pengaruh perkembangan masyarakat dengan media sosial, justru menyimpan implikasi juga tantangan baru yang hingga saat ini amat sangat harus diperhatikan. Karena jika tidak, implikasi tersebut bisa membentuk budaya baru negatif yang kedepannya akan semakin membuat memecah belah antar sesama masyarakat, bahkan hingga menimbulkan cyber chaos". Beberapa contoh kasusnya pernah dialami oleh sejumlah orang, dari mulai tokoh publik hingga rekan dekat saya.

11 Tester, Keith. 2003. Media, Budaya, dan Moralitas. Yogyakarta: Juxtapose dan Kreasi Wacana. 
Gita Savitri Devi, misalnya. Gitasav, sebutan panggilan akrabnya, merupakan tokoh publik asal Indonesia yang kini tinggal di Jerman, yang tidak pernah absen di Instagram dan YouTube. Gitasav pertama dikenal melalui konten-konten video di YouTubenya yang memberikan inspirasi bagi banyak penonton tentang kehidupan dan perjalanan menempuh studi di Jerman. Perlahan, Gitasav semakin dikenal dan terkenal di media sosial. Bahkan, Gitasav pun kini menjadi brand endorsement yang menerima untuk di endorse barang ataupun jasa.

Akan tetapi, seiring semakin dikenal dan terkenalnya tersebut, Gitasav mengalami berbagai perilaku tindakan buruk yang disampaikan antar sesama pengguna media sosial/masyarakat digital. Dari mulai hate speech, cyber bullying, hingga sexual harrasment, pernah Gitasav alami melalui kolom-kolom komentar dan direct message media sosialnya. Gitasav menilai, bahwa perilaku buruk ini jelas melanggar etika dalam bermedia sosial (netiquette) yang jika dianggap lumrah dan suatu resiko dalam bermedia sosial, maka akan semakin membuat perilaku masyarakat semenamena terhadap antar sesama, mengabaikan kepeduliaan, tidak saling memahami, bahkan acuh tak acuh.

Contoh kedua yaitu yang pernah dialami oleh rekan dekat saya. Suatu ketika, ia pernah mempublikasikan foto dirinya lengkap menggunakan beskap Jawa. Karena ia mempunyai banyak teman maya di media sosialnya, berkisar 10 menit foto dipublikasikan, teman maya yang mengomentari fotonya sudah mencapai 30 komentar. Isi komentarnya beragam, namun yang paling banyak dikomentari yaitu perihal kekurangan serta ketidakpantasan yang berujung pada bullying hingga berkatakata yang tidak sewajarnya.

Kedua contoh diatas, selaras dengan apa yang disampaikan teori khalayak kepalau batu bahwa masyarakat/teman maya berperan aktif yang tidak hanya sekedar menerima apapun yang disampaikan media, melainkan mencernanya hingga menimbulkan respon balik terhadap media. Pada konteks ini, foto ataupun video yang dipublikasikan oleh Gitasav atau rekan saya, direspon aktif oleh sesama teman maya sehingga menimbulkan respon balik bagi Gitasav atau rekan saya tersebut. Respon balik tersebut, bisa saja berupa kehati- hatian Gitasav ataupun rekan saya dalam mempublikasikan apapun di media sosial, guna mencegah respon yang tidak sewajarnya, atau bahkan merespon balik dengan membalas komentar-komentar tersebut dengan nada tegas dan keras.

Dampak lainnya dari implikasi teori khalayak kepala batu ini adalah degradasi etika dalam bermedia sosial (netiquette). Hemat penulis, jika respon aktif masyarakat dalam bermedia sosial tidak dilandasi dengan etika, justru akan menghilangkan fungsi-fungsi utama dalam berkomunikasi, yaitu memahami diri sendiri, menyelaraskan hubungan yang bermakna antar sesama, dan mengubah sikap perilaku menjadi lebih positif.

Disadari atau tidak, dari respon tanpa etika yang disampaikan melalui media sosial, perlahan akan menghilangkan rasa memahami diri sendiri bahkan minder terhadap apapun yang dilakukan oleh diri sendiri. Selain itu, rasa menyalahkan diri 
sendiri, keadaan, hingga lingkungan sekitar. Efeknya, keselarasan hubungan antar sesama pun menjadi tidak harmonis dan bermakna. Bersosialisasi menjadi segan, acuh, bahkan memungkinkan trauma untuk tidak ingin menjalin suatu pertemanan. ${ }^{12}$

Ini yang menjadi tantangan di tengah perkembangan media sosial saat ini. Etika bermedia sosial harus lebih diterapkan guna menciptakan iklim bermedia sosial yang positif, yang membawa ke arah fungsi-fungsi komunikasi sebenarnya. Fungsi-fungsi komunikasi, menjadi tujuan dasar bermedia sosial untuk senantiasa beprilaku baik dalam menggunakan media sosial.

\section{SIMPULAN}

Berdasarkan bahasan dan hasil analisa diatas, peluang yang menjanjikan jika diiringi dengan jawaban baik tantangan etika, sejatinya menjadi satu kesatuan yang nantinya akan menciptakan iklim baik dalam bermedia sosial. Masyarakat pun menjadi saling memahami dan memaknai antar satu sama lain. Tentu, dalam mengupayakan beretika dalam bermedia sosial ini, dibutuhkan banyak pihak upaya menyukseskannya. Meskipun pemerintah Indonesia beberapa waktu yang lalu sudah memberlakukan UU ITE yang pada intinya berfungsi untuk mengatur etika dan perilaku dalam bermedia sosial, kepedulian pihak lain pun tentu masih amat sangat dibutuhkan, terutama pihak masyarakat sendiri. Batasan pemerintah, hanya berada pada tataran 12 Fiske, John. 2004. Cultural and Communication Studies Sebuah Pengantar Paling Komprehensif. Yogyakarta: Jalasutra. aturan saja, sedangkan masyarakat mampu mengajak bahkan mengubah antar sesama masyarakatnya karena sudah mengetahui dan satu ruang lingkup.

Tidak ada yang harus disalahkan. Bukan pengguna yang salah, bukan pula masyarakat yang berkomentar yang salah. Semua dibutuhkan kesadaran diri sendiri upaya untuk bersama-sama diterapkan. Peluang menciptakan pekerjaan baru melalui media sosial pun lebih menjanjikan jika diikuti dengan etika dan perilaku yang baik. Jangan hanya melihat satu kekurangan, kemudian dikomentari dengan bullying, melainkan lebih memperhatikan kepekaan, kepedulian, serta dampak yang akan ditimbulkan nantinya. Jangan pula, menganggap diri kita sebagai sosok yang memang ideal dan pantas dipuji dibandingkan dengan yang lain.

Dalam kajian psikologi komunikasi, struktur kepribadian manusia dibagi kedalam tiga, yaitu id (kesenangan), ego (realitas), dan superego (moral). Ketiganya jangan hanya mengambil satu struktur lalu kemudian diterapkan. Akan tetapi, harus diambil menyeluruh guna menyelaraskan. Jika berkomentar bebas hanya akan menimbulkan kepuasan tersendiri tanpa melihat dampak realitas yang terjadi nantinya, terlebih juga berkomentar tidak baik yang tidak diiringi dengan etika, maka kepribadian manusia tersebut hanya mengandalkan id saja dalam dirinya. Asal senang, tidak peduli terhadap dampak yang ditimbulkan nantinya.

Alangkah lebih baik, jika ketiga struktur diatas diperhatikan. Berkomentar tidak hanya sekedar kesenangan, akan tetapi 
berkomentarlah dengan melihat dampak realitas yang akan ditimbulkan nanti diiringi dengan etika berkomentar yang baik. Pengguna pun, hemat penulis, akan terbuka juga saling memahami kembalijika kemudian direspon balik. Maka nantinya, tidak hanya etika baik yang diperhatikan, melainkan nilai komunikasi dalam kehidupannya pun akan dinilai baik seiring dengan apa yang ditampilkan dalam media sosial.

\section{DAFTAR PUSTAKA}

[1] Biagi, Shirley. 2010. Media/Impact Pengantar Media Massa. Terjemahan. Jakarta: Salemba Humanika.

[2] Baran, Stanley J. 2012. Pengantar Komunikasi Massa Melek Media dan Budaya. Jakarta: Erlangga.
[3] Fiske, John. 2004. Cultural and Communication Studies Sebuah Pengantar Paling Komprehensif. Yogyakarta: Jalasutra.

[4] Listiani, Endri dan Askurifa'l Baksin. 2013. Media dan Komunikasi Lingkungan. Bandung: Unisba.

[5] Liliweri, Alo. 2016. Konfigurasi Dasar Teori-Teori Komunikasi Antarbudaya. Bandung: Nusa Media.

[6] McQuail, Denis. 2011. Teori Komunikasi Massa. Terjemahan. Jakarta: Salemba Humanika.

[7] Nasrullah, Rulli. 2017. Media Sosial Perspektif Komunikasi, Budaya, dan Sosioteknologi. Bandung: Simbiosa Rekatama Media.

[8] Tester, Keith. 2003. Media, Budaya, dan Moralitas. Yogyakarta: Juxtapose dan Kreasi Wacana

[9] Instagram Gita Savitri Devi 